*als Fiew/Print Document Cover Sheet tow

This document was retrieved from the Documentation and Records Management (DRM) ISEARCH System. It is intended for Information only and may not be the most recent or updated version. Contact a Document Service Center (see Hanford Info for locations) if you need additional retrieval information.

Accession \#: D196045540

Document \#: SD-WM-ETP-188

Title/Desc:

ENGINEERING TASK PLAN TWRS TECHNICAL BASELINE COMPLETION

Pages: 16 


\begin{tabular}{|c|c|}
\hline MAR 081996 (21) ENGINEERING DATA TRANSMItTAL & 1. EDT NO 614706 \\
\hline
\end{tabular}

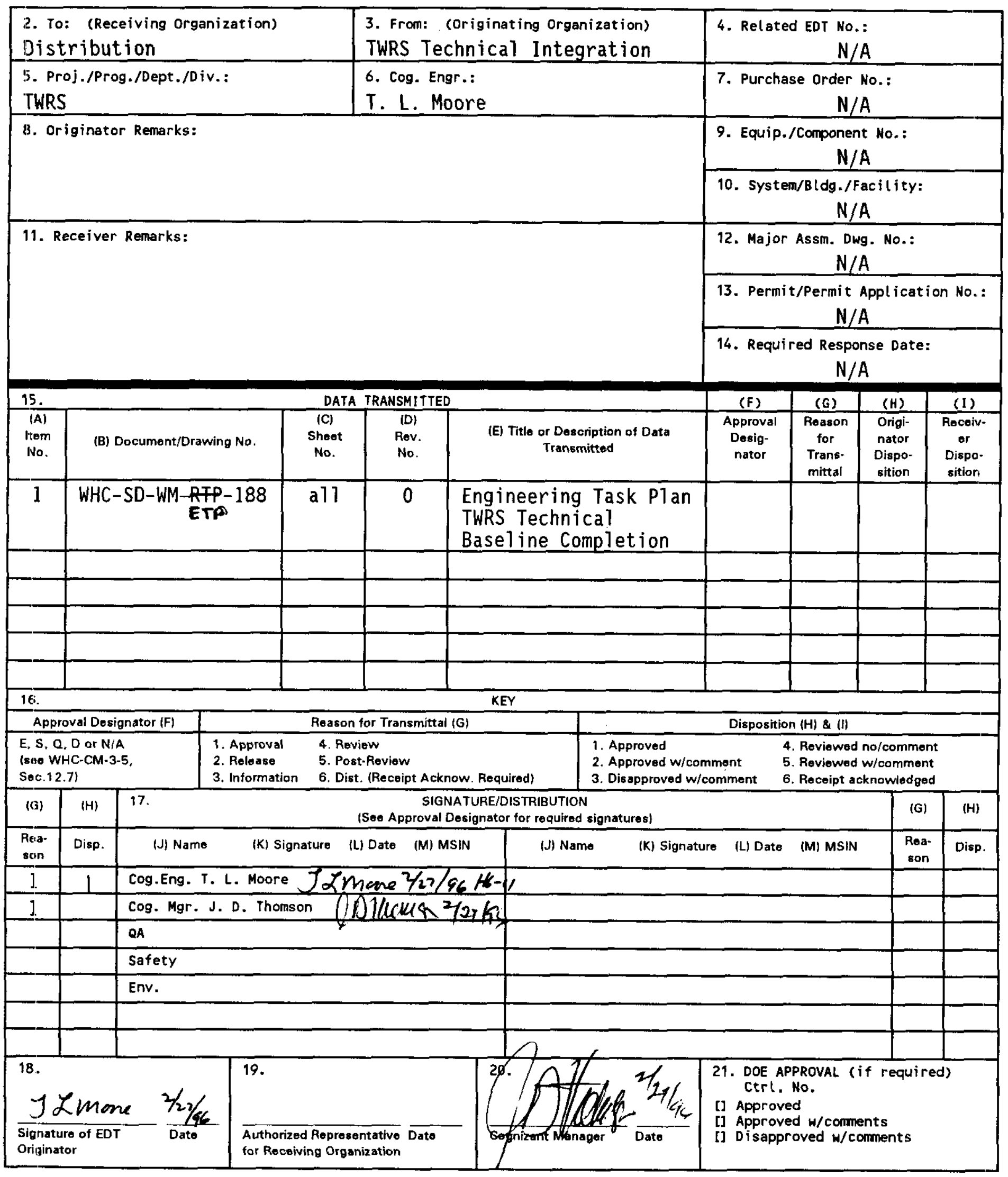




\title{
Engineering Task Plan TWRS Technical Baseline Completion
}

\author{
T. L. Moore \\ Westinghouse Hanford Company, Richland, WA 99352 \\ U.S. Department of Energy Contract DE-AC06-87RL10930

$\begin{array}{lll}\text { EDT/ECN: } & 614706 & \text { UC: } 900 \\ \text { Org Code: } & 74400 & \text { Charge Code: } \\ \text { B\&R Code: } & \text { EW3120075 } & \text { Total Pages: } 13\end{array}$

Key Words: Baseline, TWRS, Schedule, Functions, Requirements, Architecture, Test, Systems Engineering Baseline Team

Abstract: The Tank Waste Remediation System (TWRS) includes many activities required to remediate the radioactive waste stored in underground waste storage tanks. These activities include routine monitoring of the waste, facilities maintenance, upgrades to existing equipment, and installation of new equipment necessary to manage, retrieve, process, and dispose of the waste. In order to ensure that these multiple activities are integrated, cost effective, and necessary, a sound technical baseline is required from which all activities can be traced and measured. The process by which this technical baseline is developed will consist of the identification of functions, requirements, architecture, and test (FRAT) methodology. This process must be completed for TWRS to a level that provides the technical basis for all facility/system/component maintenance, upgrades, or new equipment installation.

TRADEMARK DISCLAIMER. Reference herein to any specific comercial product, process, or service by trade name, trademark, manufacturer, or otherwise, does not necessarily constitute or imply its endorsement, recommendation, or favoring by the United States Government or any agency thereof or its contractors or subcontractors.

Printed in the United States of America. To obtain copies of this document, contact: WHC/BCS Document Control Services, P.O. Box 1970, Mailstop H6-08, Richland WA 99352, Phone (509) 372-2420; Fax (509) 376-4989.
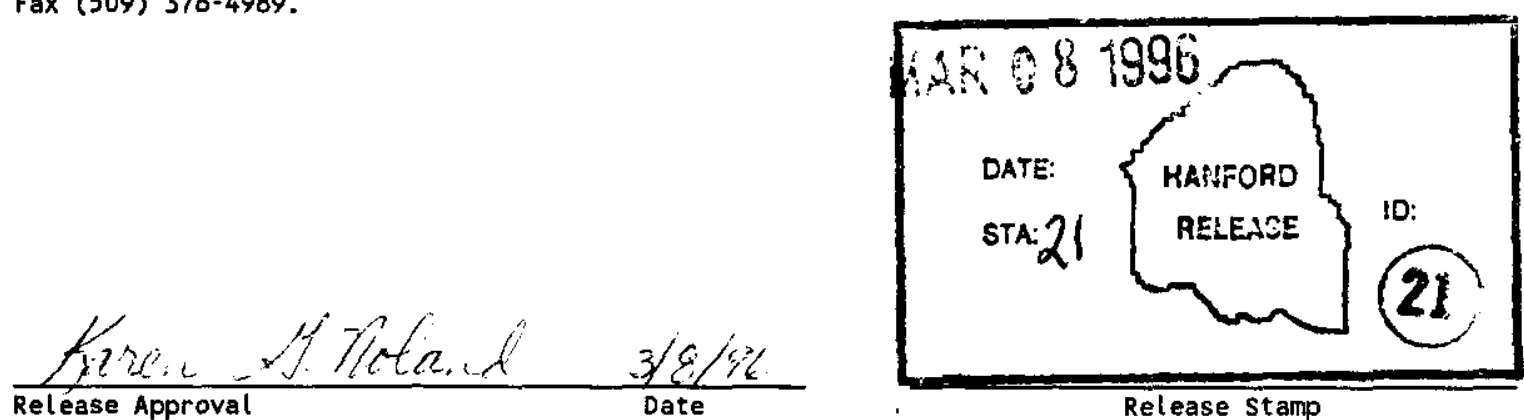

Approved for Public Release 
WHC-SD-WM-ETP-188 Rev. 0

CONTENTS

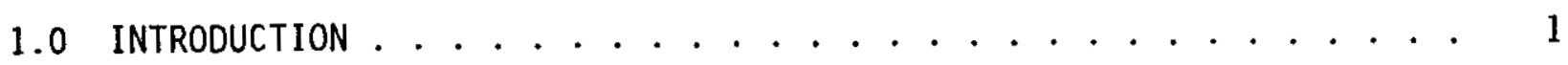

2.0 SCOPE

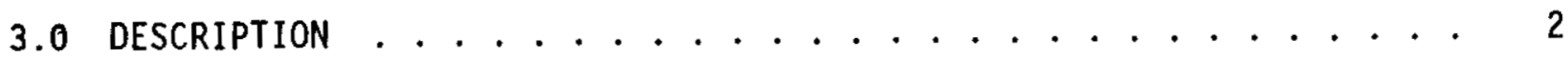

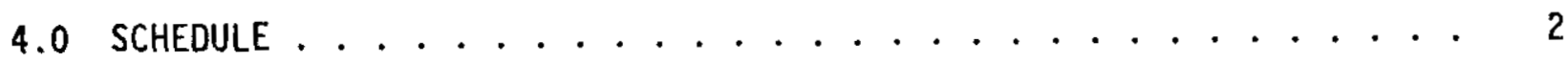

ATTACHMENT $1 \ldots \ldots \ldots \ldots \ldots \ldots$

ATTACHMENT $2 \ldots \ldots \ldots \ldots \ldots \ldots$

ATTACHMENT $3 \ldots \ldots \ldots \ldots \ldots$ 


\section{ENGINEERING TASK PLAN \\ TWRS TECHNICAL BASELINE COMPLETION}

\subsection{INTRODUCTION}

The Tank Waste Remediation System (TWRS) includes many activities required to remediate the radioactive waste stored in underground waste storage tanks. These activities include routine monitoring of the waste, facilities maintenance, upgrades to existing equipment, and installation of new equipment necessary to manage, retrieve, process, and dispose of the waste. In order to ensure that these multiple activities are integrated, cost effective, and necessary, a sound technical baseline is required from which all activities can be traced and measured. The process by which this technical baseline is developed will consist of the identification of functions, requirements, architecture, and test (FRAT) methodology. This process must be completed for TWRS to a level that provides the technical basis for all facility/system/component maintenance, upgrades, or new equipment installation.

\subsection{SCOPE}

\subsection{OBJECTIVES}

On or before March 2, 1996:

1. Demonstrate traceability of TWRS Functions and Requirements Baseline to U.S. Department of Energy (DOE), Richland Operations Office (RL) approved mission requirements as contained within the TWRS Mission Analys is Report, WHC-SD-WM-MAR-008 (Knutson 1995) ${ }^{1}$.

2. Demonstrate that the Baseline contains system definition through the TWRS Function Level 3, including the FRAT methodology.

3. Demonstrate that the Baseline contains system definition through the TWRS Function Level 4, including functions and requirements.

4. Demonstrate traceability of changes to the Baseline identified in the DOE, Headquarters (HQ) Systems Requirements Review (SRR) and the current revision of the RL SRR Action Plan.

5. Establish in the Baseline database a correlation of functions to Work Breakdown Structure (WBS) program elements.

6. Obtain approval of the Baseline from the WHC TWRS Program Manager.

7. Obtain acceptance of the Baseline by the responsible technical experts within RL.

\footnotetext{
1'Knutson, 1996, Tank Waste Remediation Systen Mission Analysis Report, WHC-SD-WM-MAR-008, Rev. O, West inghouse Hanford Company, Richland, Washington.
} 
On or before June 1, 1996:

1. Complete development and technical reviews of the Baseline down to a level that provides technical bases for projects (technical assessment of existing facility systems, facility/system upgrades, or new facility/system installation). This includes the FRAT methodology, which is ready for approval by the WHC TWRS Program Manager.

2. Provide document formats for Functions and Requirements and Interface Control Documents that are user friendly as judged by WHC gatekeepers and RL technical experts.

3. Provide a status on any SRR actions not completed by March 2, 1996.

\subsection{DESCRIPTION}

A Systems Engineering Baseline Team (SEBT) has been formed which is chartered to facilitate development and deployment of integrated technical basis documentation for the TWRS Program (see Attachment 1). This team is identified in Attachment 2 along with the main WHC program/project and RL interfaces. The SEBT members will work with staff from the appropriate program offices and technical organizations within TWRS, as we 11 as the responsible RL technical experts to ensure that a TWRS baseline is developed, reviewed, approved, and accepted as described in Section 2.1. The SEBT will provide support to the program offices as well as leading the integration of all activities necessary to complete the task as described in Section 2.0. This includes arranging for the appropriate WHC and WHC/DOE integrated reviews, documenting changes to the baseline resulting from these reviews, maintaining configuration control over the baseline, identifying and resolving issues arising from the reviews, and any other integrating/coordinating task that is necessary to ensure successful completion of the objectives of this activity.

\subsection{SCHEDULE}

See Attachment 3 . 
WHC-SD-WM-ETP-188 Rev. 0

\section{ATTACHMENT 1}

\subsection{CHARTER}

The Systems Engineering Baseline Team (SEBT) is chartered to facilitate development and deployment of integrated technical basis documentation for the Tank Waste Remediation System (TWRS) program. The SEBT provides up-front leadership to integrate the 4.2.X level Functions and Requirements baseline for TWRS to ensure that all TWRS activities have a documented technical basis necessary to demonstrate progress toward accomplishing the TWRS mission.

\subsection{RESPONSIBILITIES}

2.1 Produce TWRS functions and requirements documents that are user friendly and easily accessed and used by engineering staff. This will include disposition of TWRS technical basis integration issues.

2.2 Provide and status a schedule that will ensure completion of the TWRS Functions and Requirements Baseline to a level where projects and upgrade and maintenance activities can be defined. This includes identification of issues and trade studies required to support activity definition.

2.3 Support the Contract Support Team activities as necessary to issue and award Phase I Privatization contracts.

2.4 Work with the program offices to provide integration support necessary to develop and document the TWRS functions and requirements baseline.

2.5 Provide leadership to conduct necessary briefings to complete proper reviews and gain acceptance of the TWRS functions and requirements baseline.

2.6 Identify critical areas in the program that require improved technical integration activities. 
WHC-SD-WM-ETP-188 Rev. 0

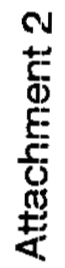
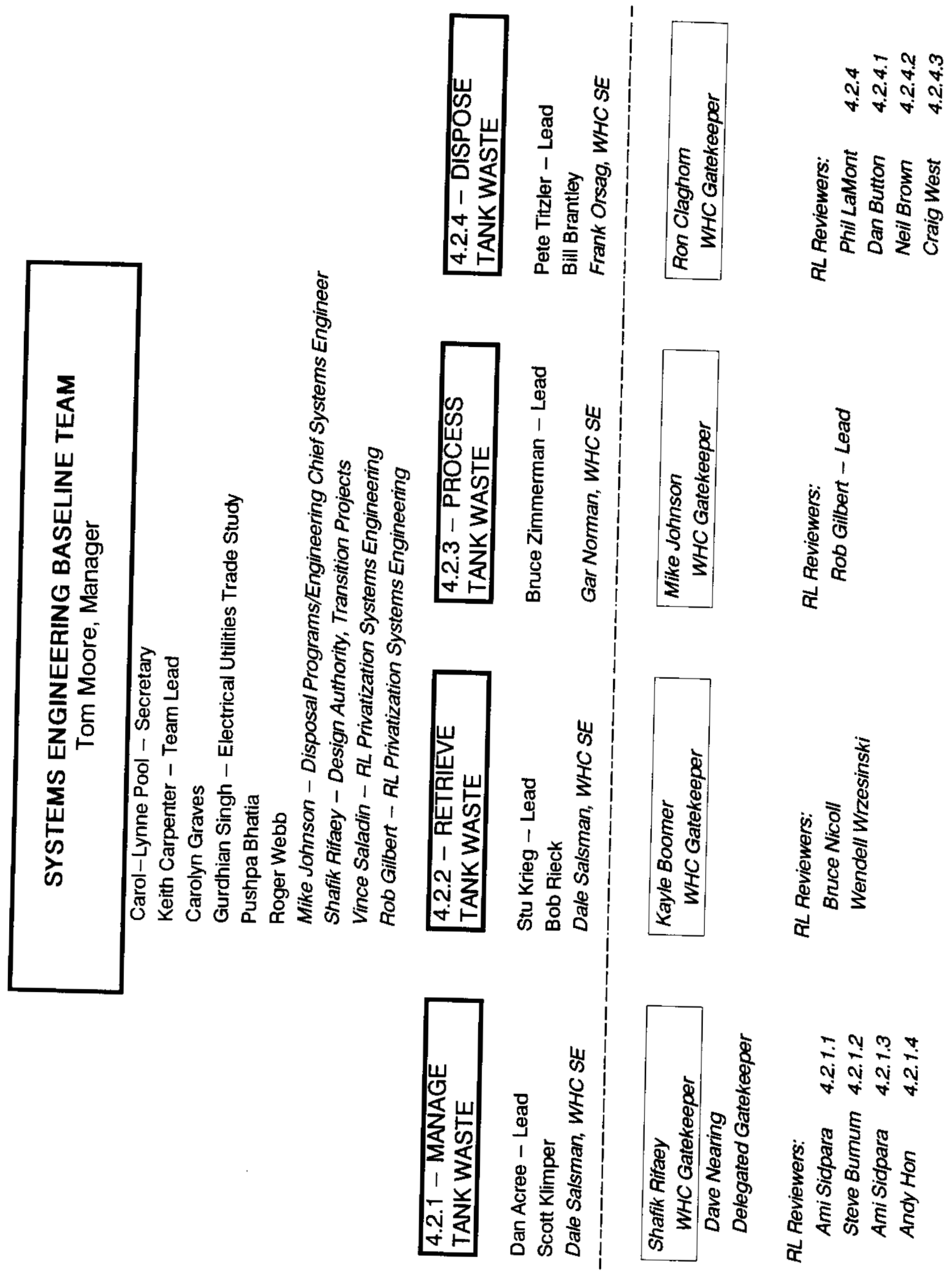
WHC-SD-WM-ETP-188 Rev. 0

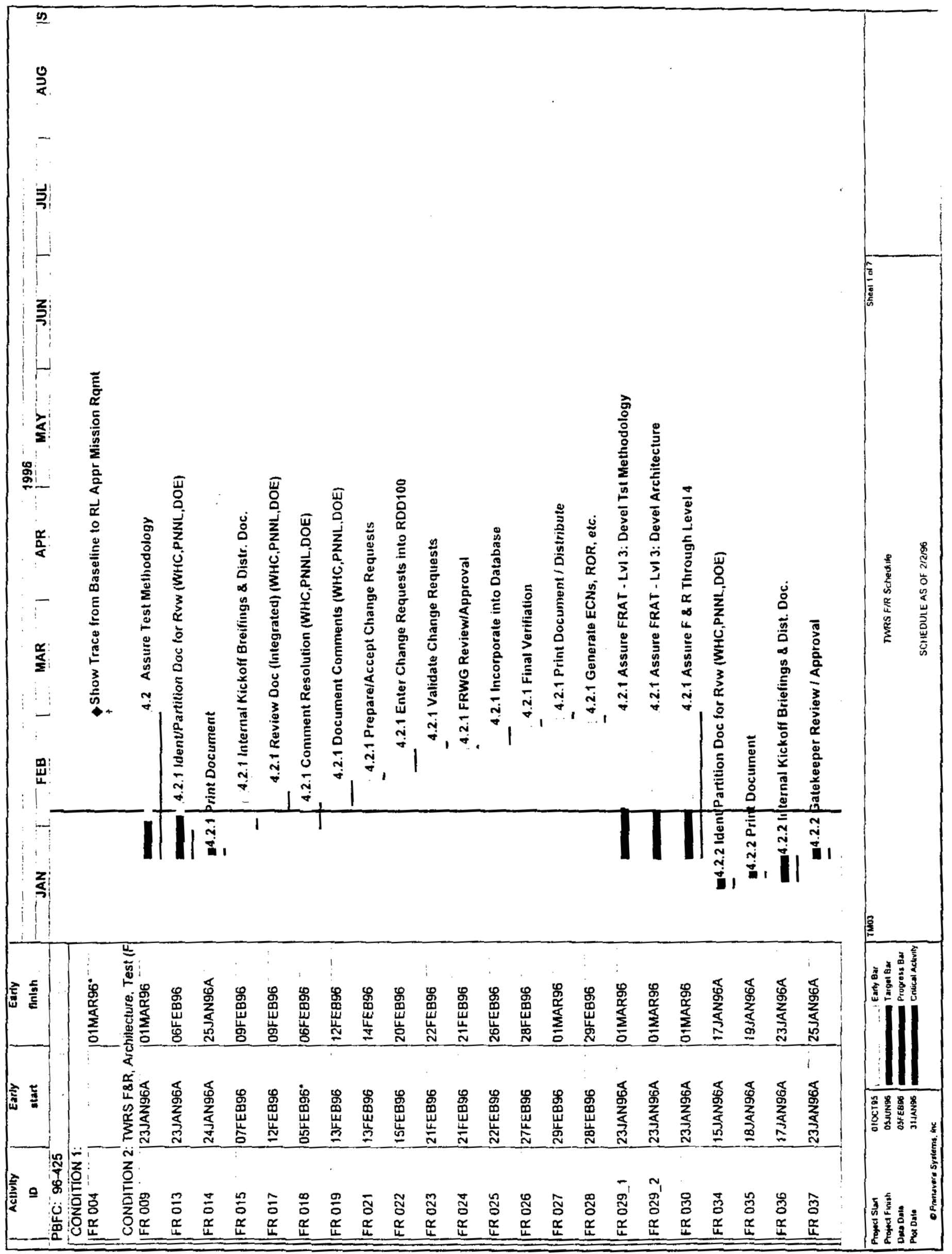


WHC-SD-WM-ETP-188 Rev. 0

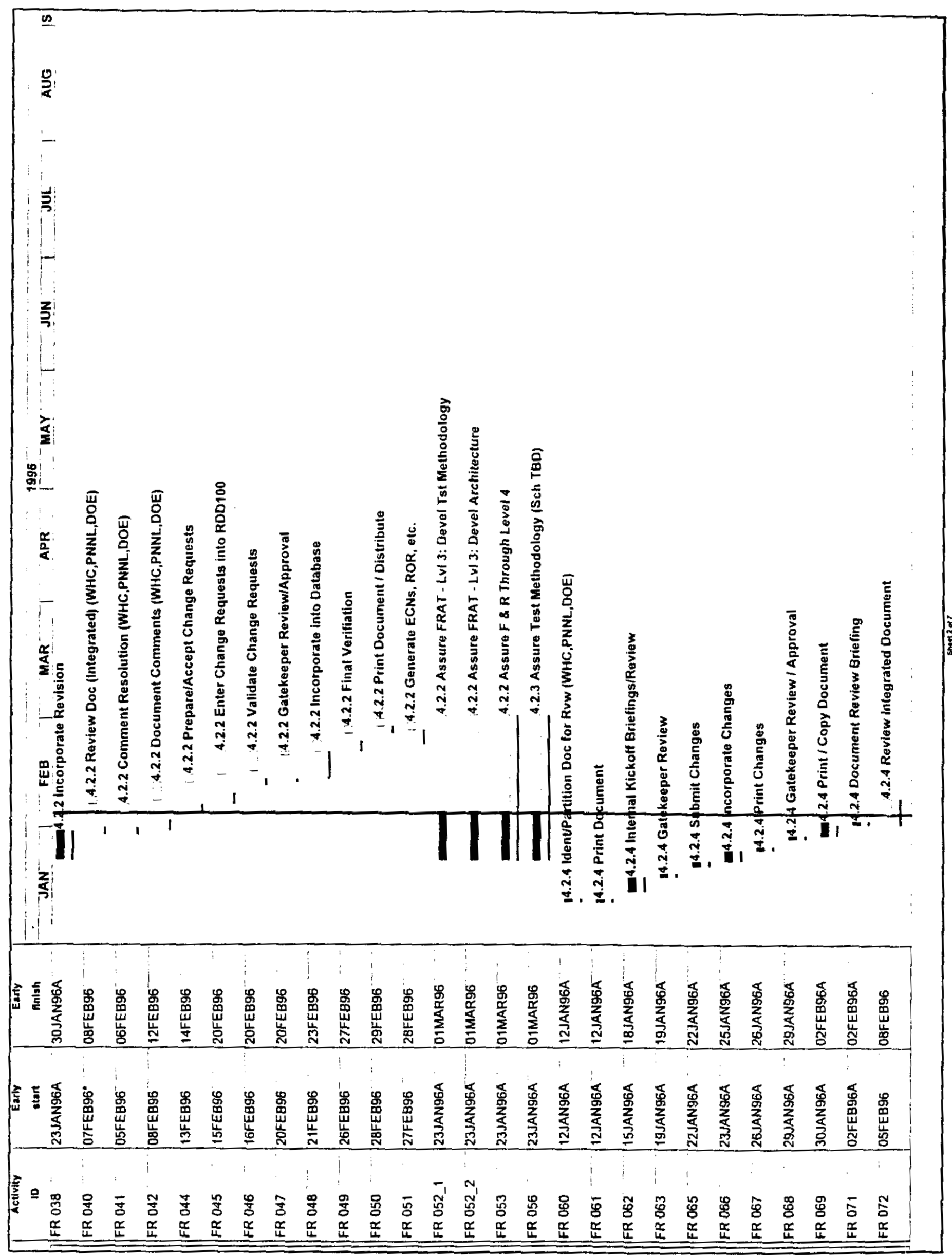




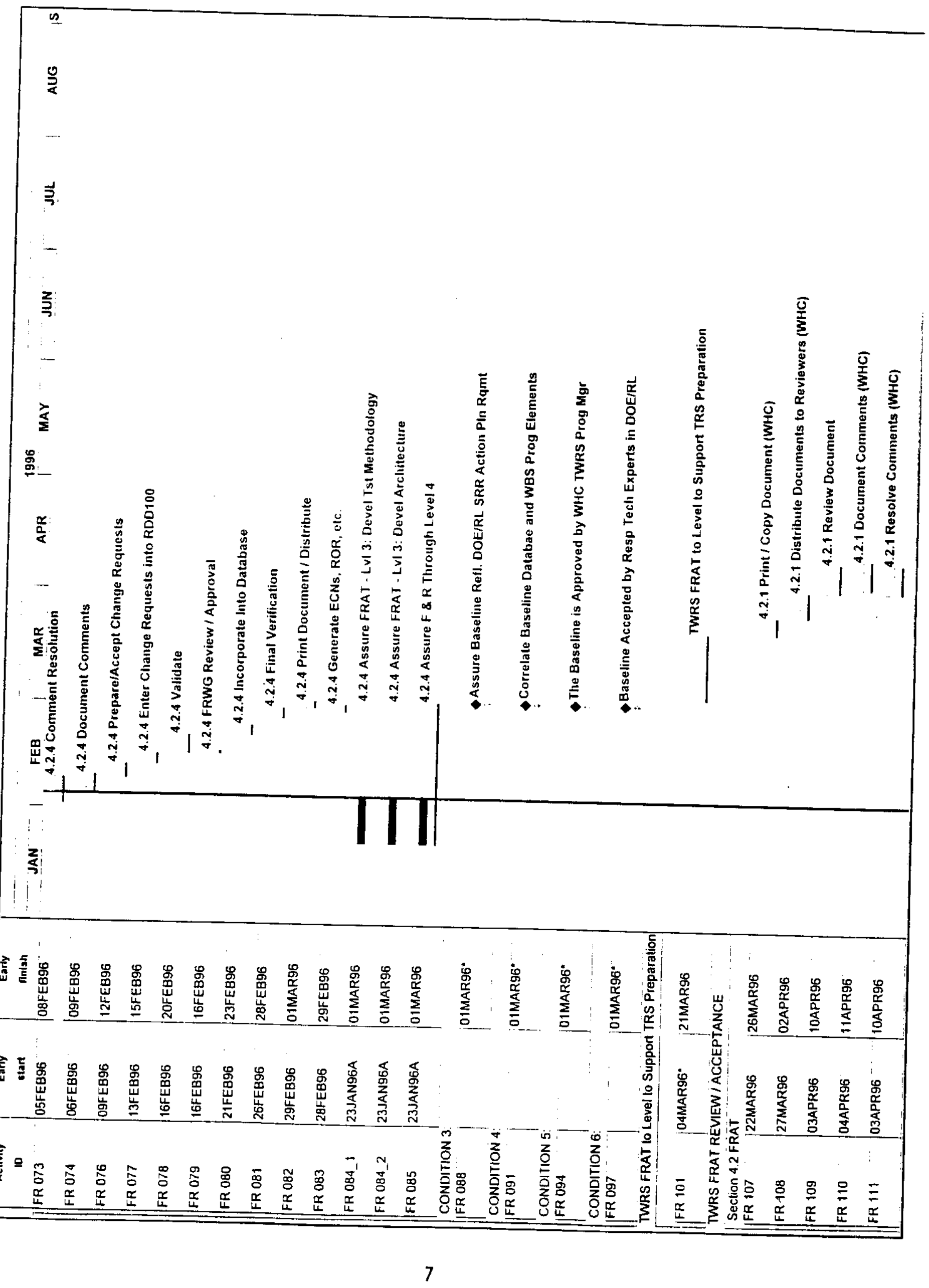




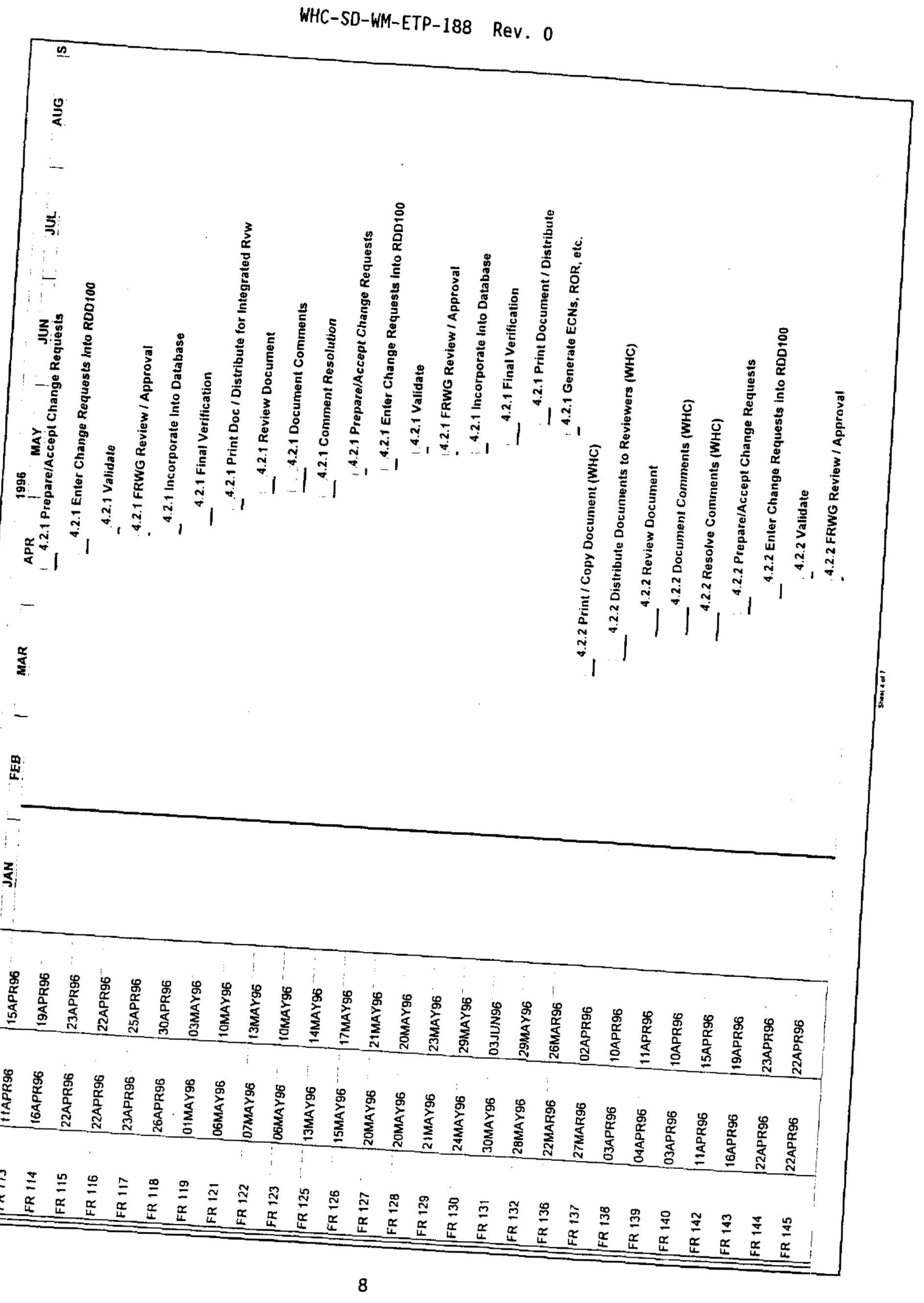


WHC-SD-WM-ETP-188 Rev. 0

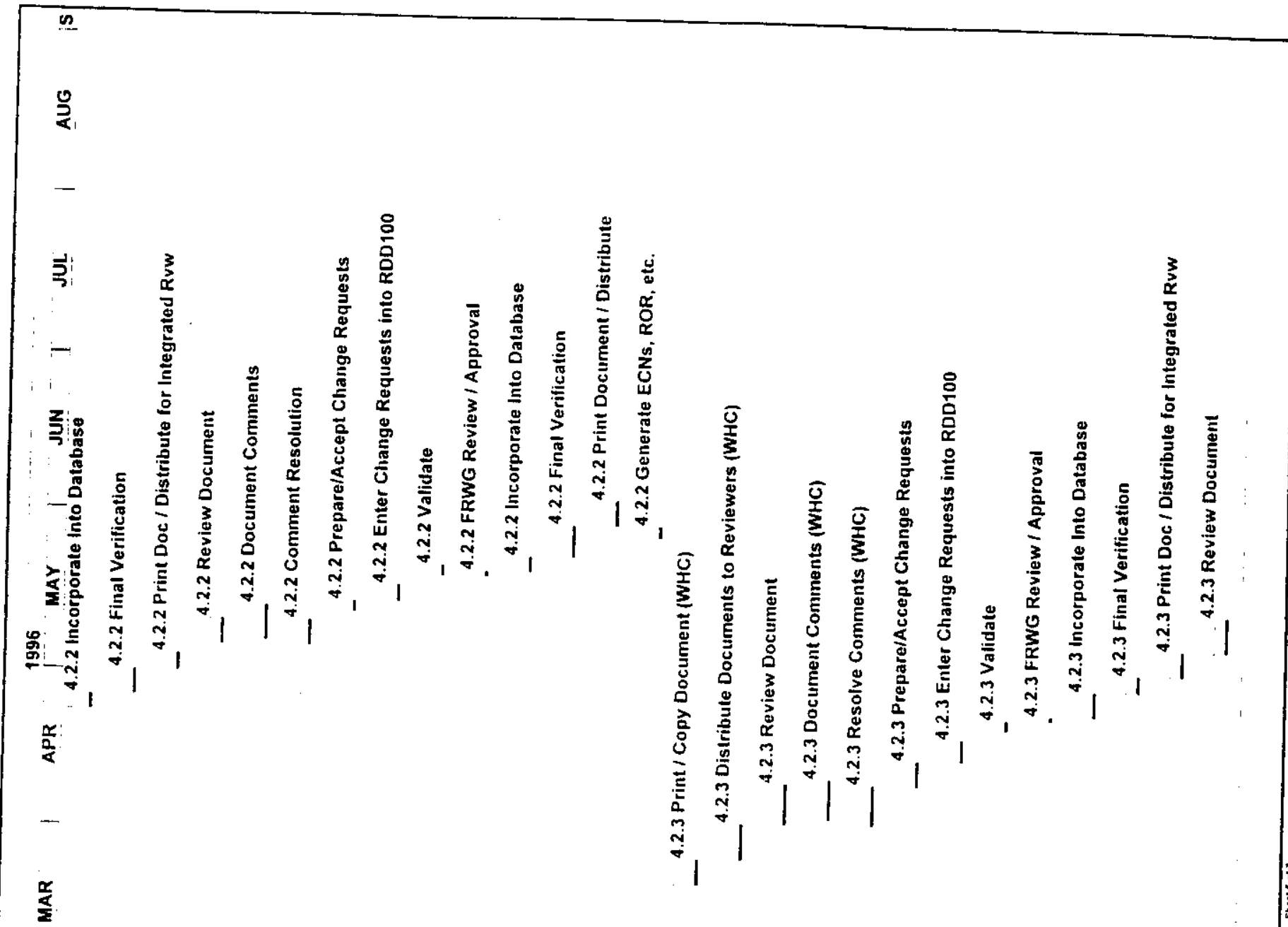

$\frac{z}{5}$

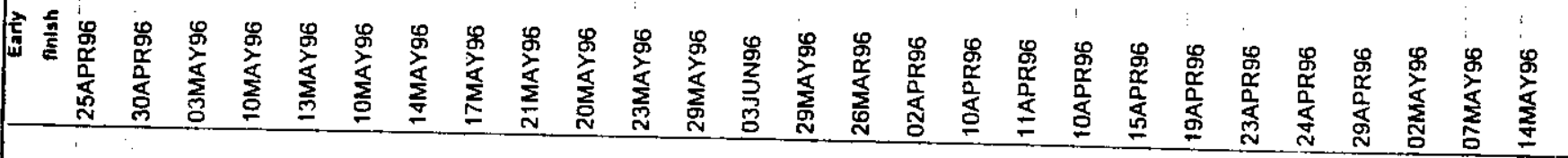

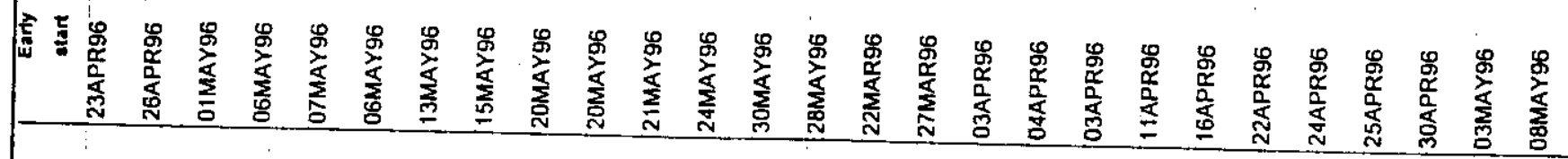

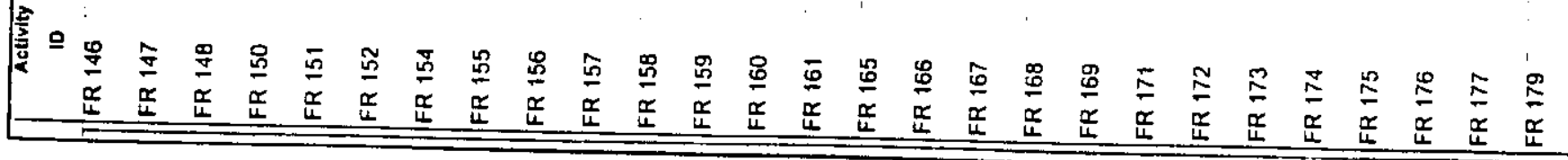




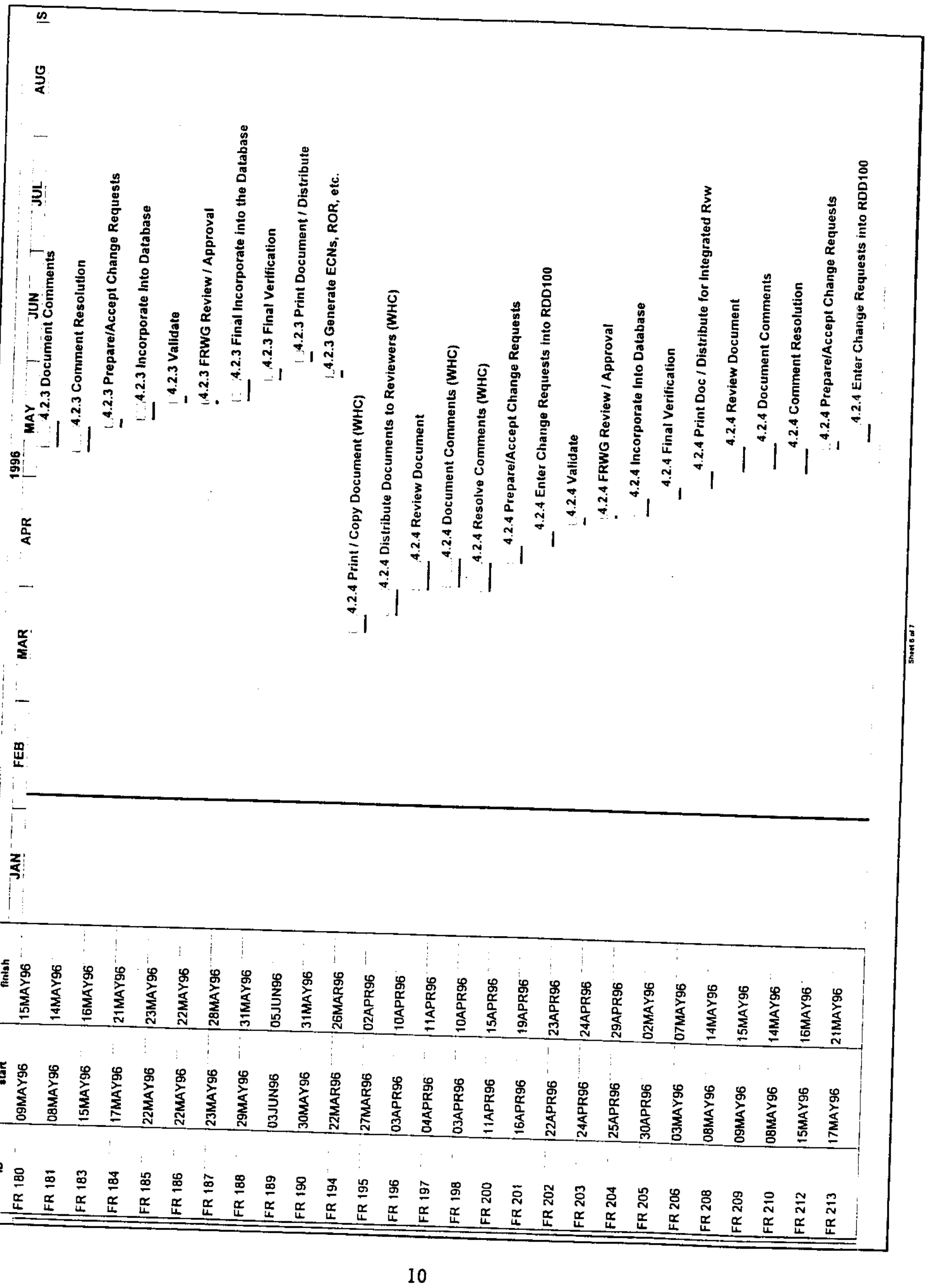




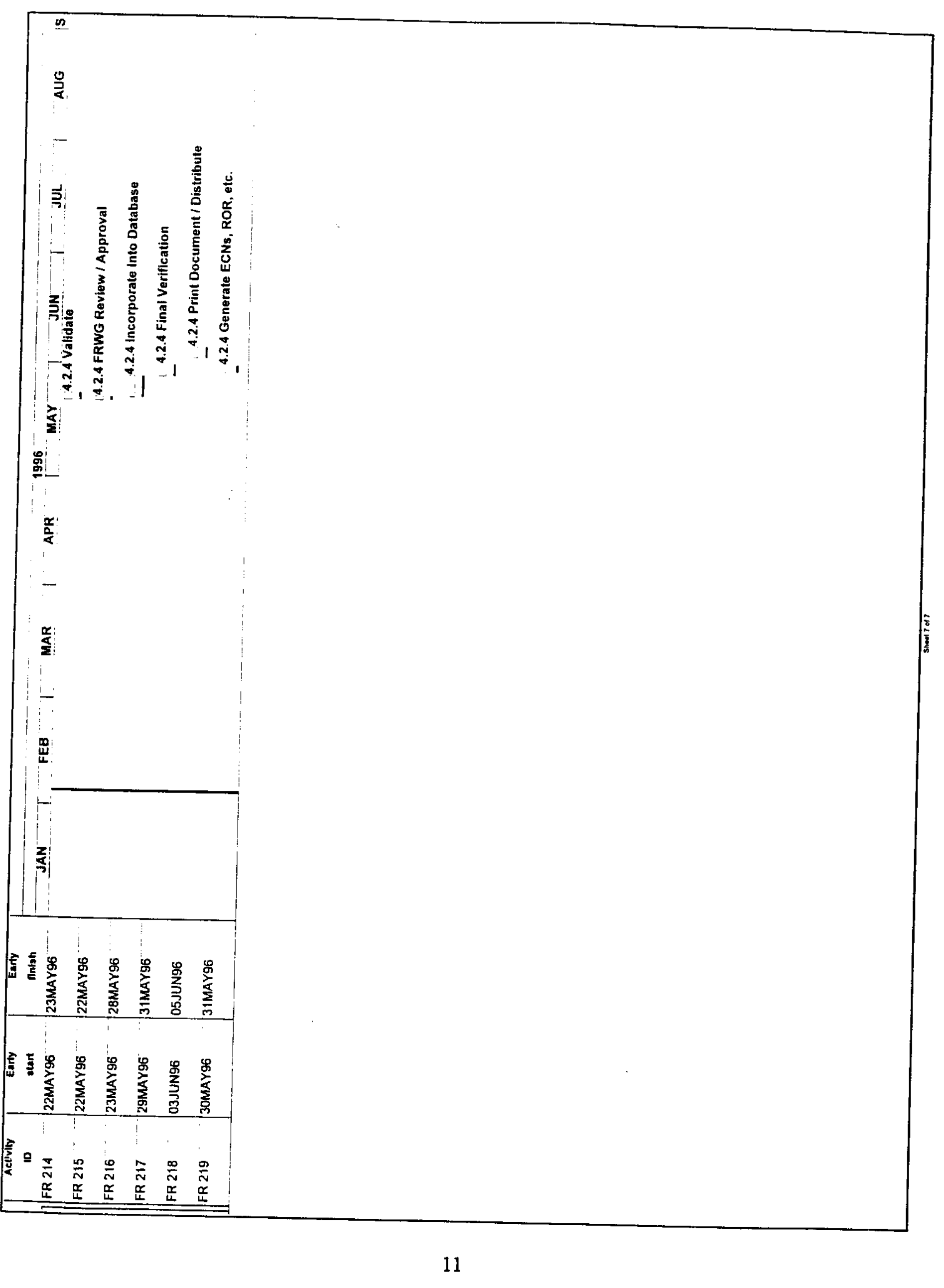




\begin{tabular}{|c|c|c|c|c|c|c|}
\hline \multicolumn{7}{|c|}{ DISTRIBUTION SHEET } \\
\hline To & \multirow{2}{*}{\multicolumn{4}{|c|}{$\begin{array}{l}\text { From } \\
\text { TWRS Technical Integration }\end{array}$}} & \multicolumn{2}{|l|}{ Page 1 of 1} \\
\hline Distribution & & & & & \multicolumn{2}{|c|}{ Date $02 / 21 / 96$} \\
\hline \multirow{2}{*}{$\begin{array}{l}\text { Froject Title/Work Order } \\
\text { WHC-SD-WM-ETP-188 Rev. } 0\end{array}$} & & & & & \multirow{2}{*}{\multicolumn{2}{|c|}{\begin{tabular}{|ll} 
EDT No. & 614706 \\
ECN No. & N/A \\
\end{tabular}}} \\
\hline & & & & & & \\
\hline Name & & MSIN & $\begin{array}{l}\text { Text } \\
\text { With All } \\
\text { Attach. }\end{array}$ & Text Only & $\begin{array}{l}\text { Attach.l } \\
\text { Appendix } \\
\text { Only }\end{array}$ & $\begin{array}{l}\text { EDT/ECN } \\
\text { Only }\end{array}$ \\
\hline $\begin{array}{l}\text { J. D. Thomson } \\
\text { L. G. Peck } \\
\text { N. G. Awadall } \\
\text { C. W. Dunbar } \\
\text { T. L. Moore } \\
\text { C. C. Scaief } \\
\text { D. B. Smet } \\
\text { J. L. Homan } \\
\text { R. K. Brown }\end{array}$ & $H 6-11$ & $\begin{array}{r}H 6-35 \\
H 6-35 \\
H 6-35 \\
H 6-35 \\
-R 2-76- \\
\text { S2-02 } \\
\text { N1 }-46 \\
H 5-09 \\
H 5-68 \\
\end{array}$ & $\begin{array}{l}x \\
x \\
X \\
x \\
X \\
x \\
X \\
x \\
x\end{array}$ & & & \\
\hline Central Files & & A3-88 & $x$ & & & \\
\hline
\end{tabular}

